\title{
Radiographic Observation of the Internal Porosities in Castings of High Fusible Base Alloy
}

\author{
Haruyuki KAWAHARA, Nobuhiro ISHIZAKI, Takatoshi MAEDA and Hiroki SAKAE \\ Department of Biomaterials, Osaka Dental University 1-47 Kyobashi, Higashiku, Osaka 540, Japan
}

Received on March 31, 1984

In order to investigate internal porosities of high fusible base alloy castings, non-destructive inspection was carried out by radiographic method with an X-ray unit. Test samples were made of cobalt-chromium and nickel-chromium alloys, and shaped into 13 steps of wedge type castings with the minimum thickness of $0.35 \mathrm{~mm}$ and maximum thickness of $4.55 \mathrm{~mm}$ in an incremental increase of $0.35 \mathrm{~mm}$. It was found that the X-ray unit could provide clear radiographs. The internal porosities of metal denture frame, crown-bridge and dental implant made of base alloy were easy to interpret by setting the exposure time to 90 seconds with three tube voltages of 50,60 and $70 \mathrm{kVp}$ according to thickness of castings.

Key Words: Radiographic Observation, Internal Porosity, Base Alloy Castings

\section{INTRODUCTION}

Base alloys of cobalt-chromium and nickel-chromium have been used in dentistry. These alloys have good corrosion resistant, high mechanical strength, light gravity and suitable biocompatibility without any irritation to the living tissues ${ }^{1)}$.

Kawahara et al. $(1972,1973)$ reported that these mechanical properties are equivalent to those of the precious alloys ${ }^{2,3}$. Considering the cost of precious metals and their possible shortage in the future, it is natural that many cobalt-chromium and nickel-chromium alloys are used not only for metal plate denture but also for crown-bridges, and porcelain fused metal crowns in dentistry. The amount of these alloys used in dentistry has been increasing with a remarkable progress in the casting system for high fusible base alloys ${ }^{4,5}$. Particularly cobalt-chromuim-morybdenum alloys have been used with favorable results in dental implantology. This indicates that the base alloys are not a substitute but are useful for dental and medical prosthesis. The recent progress of casting apparatus has made a significant improvement for precious alloys and its casting procedure has been almost established. Therefore, the very fine castings with high dimensional accuracy have come to be applied to precious alloys. However, regarding the base alloys, it seems to be very difficult to produce castings with high dimensional accuracy. In addition, there are some problems such as casting defects, particularly casting porosity occurs inside the castings which are most detrimental for prosthetic appilances, especially dental implants used in living tissue. It could extremely degrade mechanical properties of the prosthetic appliances and may cause serious accidents during mastication ${ }^{6 \sim 8)}$.

Quality of castings has been evaluated by the observation on its outer appearance. However, it is necessary to investigate the inside of castings with a non-destructive method. 
Therefore, the authors developed Bio-X* X-ray unit to examine the internal porosities of base alloy castings with short time, low cost and high accuracy ${ }^{9 \sim 10}$.

\section{MATERIALS AND METHODS}

Materials of test sample

Bionium $^{9,12)}$, a cobalt-chromium alloy developed particularly as a metallic material for dental implants and Wiron ${ }^{9)}$ of iron-nickel-chromium alloy which is marketed as a coping metal for porcelain fused metal crown were used as test samples.

Shape of test sample

Test samples were shaped into step wedge type as in Figure 1, which is the most suitable shape to evaluate the internal porosity in dental castings. Among the prosthetic appliances and implants, the minimum thickness is $0.3 \mathrm{~mm}$ at the palatal part of metal plate denture, while the maximum thickness is about $4.0 \mathrm{~mm}$ at the abuttment head of subperiosteal implants. To make the step wedge type of test sample, sheet wax of $0.35 \mathrm{~mm}$ thickness was layered from the minimum thickness of $0.35 \mathrm{~mm}$ to the maximum thickness of $4.55 \mathrm{~mm}$. These wax patterns were cast with Bionium and Wiron.

X-ray unit

The Bio-X apparatus, an X-ray unit for base alloy castings, has been already used in the Bionium system for subperiosteal implant ${ }^{12}$. The apparatus shown in Figure 2. Particularly the target size of the X-ray tube was $1 \times 1 \mathrm{~mm}$ so as to provide clear raiodgraphic views.



Figure 1 Step wedge type of test sample

* MRO-10R, International Tokyo seimitsu 


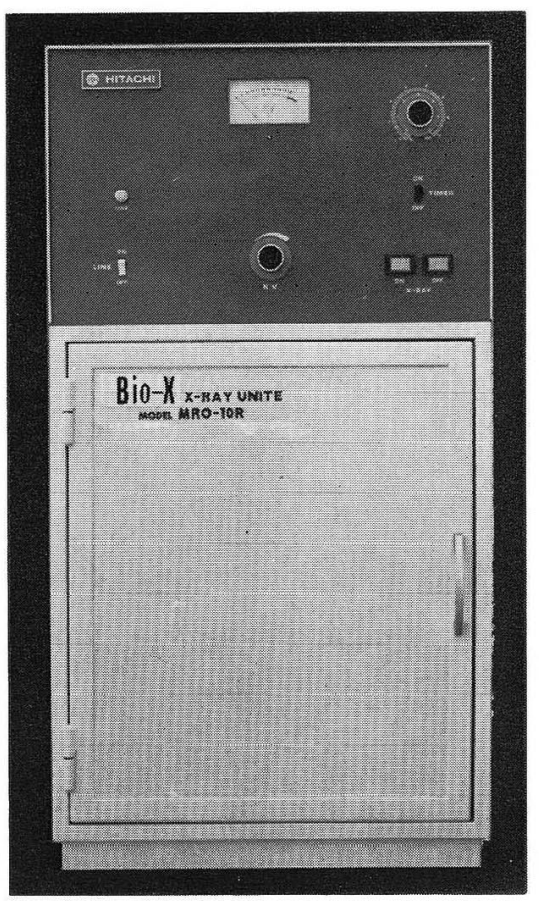

Figure 2 X-ray unit of Bio-X (MRO-10R, International Tokyo seimitsu).

\section{Conditions of exposure}

Non-destructive radiographic tests are available not only for metals but also for wooden and plastic materials. The tube voltage below $50 \mathrm{kVp}$ seems to be used for materials with low density. Therefore, the conditions of the X-ray exposure in this experiments were set as shown in Table.

The radiographic films of fine grain emulsion type, $\mathrm{I}-\mathrm{X}^{*}$ were used with $0.03 \mathrm{~mm}$ lead

Table Exposure condition of X-ray irradiation.

\begin{tabular}{|c|c|c|c|c|c|}
\hline \multicolumn{6}{|c|}{ Exposure time (Sec.) } \\
\hline & 150 & 120 & 90 & 60 & 30 \\
\hline \multirow{9}{*}{ 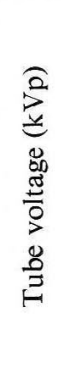 } & 20 & Y & Y & / & / \\
\hline & 30 & 30 & ノ & / & Y \\
\hline & 40 & 40 & 40 & l & / \\
\hline & 50 & 50 & 50 & 50 & Y \\
\hline & 60 & 60 & 60 & 60 & 60 \\
\hline & 70 & 70 & 70 & 70 & 70 \\
\hline & 80 & 80 & 80 & 80 & 80 \\
\hline & 90 & 90 & 90 & 90 & 90 \\
\hline & $\gamma$ & 100 & 100 & 100 & 100 \\
\hline
\end{tabular}

\footnotetext{
* Fuji film Ind.
} 
screens. Acedole* and Superfix** were used for developing. Developing time is 5 minutes and $20^{\circ} \mathrm{C}$ according to the manufacturer's instruction. However, in this experiment, a developing time of two minutes at $22^{\circ} \mathrm{C}$ was suitable.

Developed films showed sharp and clear views to analyze the internal porosity of castings. The developed films of radiograph were examined by the densitometer*** for quantitative evaluation on the test samples. The densitometer was adjusted so that the meter scale indicated 10 at a site of image which was black of $100 \%$ exposure of X-ray and 0 at a site which was translucent of $0 \%$ exposure, and suitable scale for densitometric interpretation indicated 4.0 through 7.5 by the densitometer. All radiographs were measured based on this calibration.

\section{RESULTS}

150 seconds exposure: This is the maximum time of exposure in this experiments and
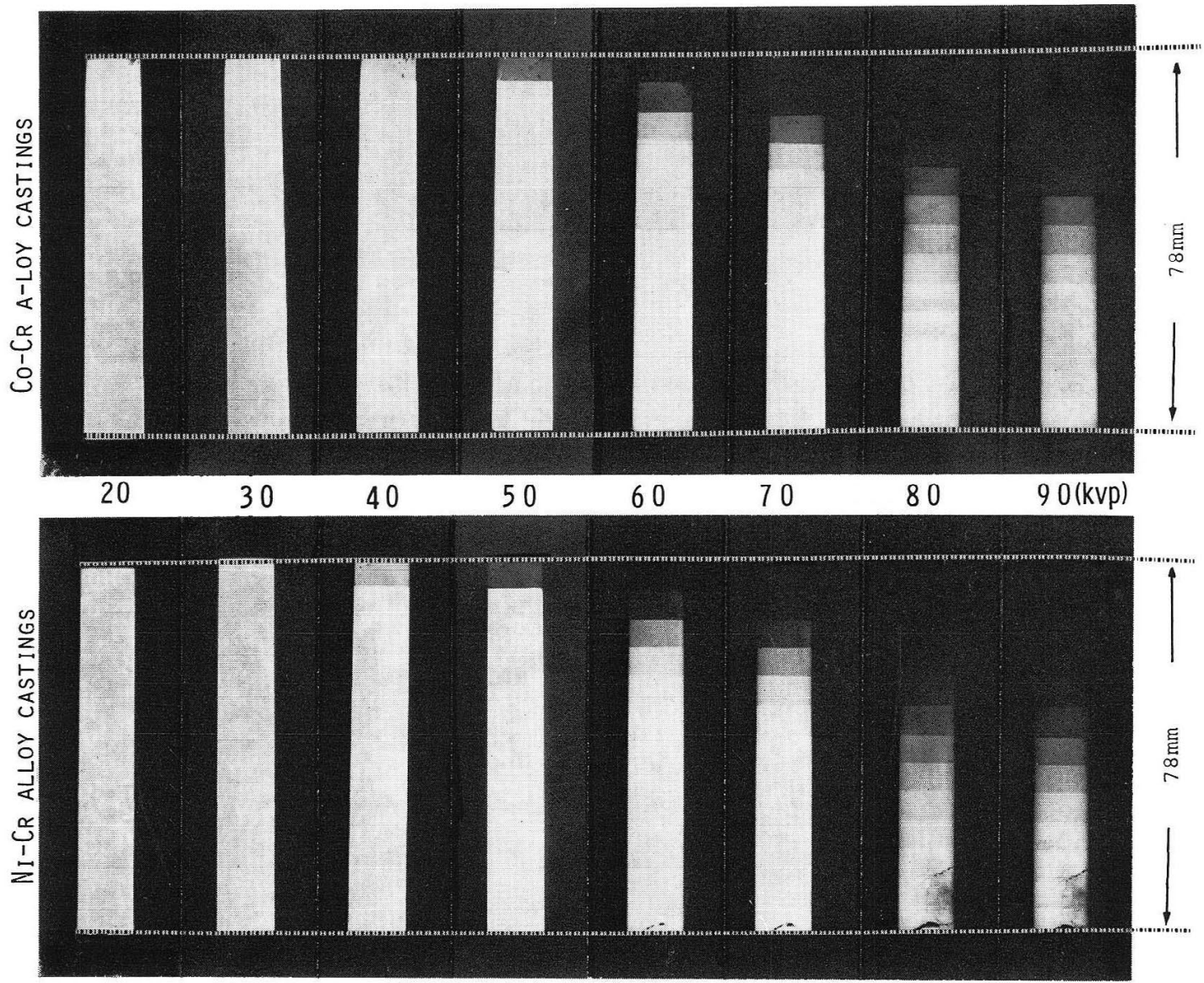

Figure 3 Radiographs of 150 seconds exposure with various tub tube voltages.

\footnotetext{
* Konishiroku

** Fuji film Ind.

*** DMU-33C, Toyo
} 
the result is shown in Figure 3. At $20 \mathrm{kVp}$ and $30 \mathrm{kVp}$ of tube voltage, it was impossible to observe even part 1 of the minimum thickness of $0.35 \mathrm{~mm}$, due to under exposure. The porosities in part 1 could be observed at $50 \mathrm{kVp}$ in both alloys of $\mathrm{Co}-\mathrm{Cr}$ and $\mathrm{Ni}-\mathrm{Cr}$. At $60 \mathrm{kVp}$, parts 3 and 4 of the Co-Cr test sample could be intrepreted. On the other hand, part 3 of Ni-Cr test sample could not be clearly inspected due to excessive exposure but part 4 could be interpreted. At $70 \mathrm{kVp}$, parts 5 and 6 of Co-Cr test sample and parts 5 through 7 of Ni-Cr test sample showed relatively suitable radiographical density and could be interpreted. At $80 \mathrm{kVp}$, parts 8 through 13 of $\mathrm{Co}-\mathrm{Cr}$ test sample and parts 9 through 13 of $\mathrm{Ni}-\mathrm{Cr}$ test sample could be interpreted. At $80 \mathrm{kVp}$, however, the exposure density tended to be too high in all parts, so that this tube voltage was the upper limit for interpretation in the case of 150 seconds exposure.

120 seconds exposure: The radiographs at $30 \mathrm{kVp}$ and $40 \mathrm{kVp}$ were impossible for interpretation due to under-exposure. At $50 \mathrm{kVp}$, the part 1 of $\mathrm{Co}-\mathrm{Cr}$ alloy could be barely interpreted with scale 4.0 by the densitometric method. Interpretation of part 2 at $60 \mathrm{kVp}$ was impossible due to over-exposure. Part 3 of both alloys could be interpreted. At $70 \mathrm{kVp}$ parts 4 through 6 of $\mathrm{Co}-\mathrm{Cr}$ alloy and parts 5 through 7 of $\mathrm{Ni}-\mathrm{Cr}$ alloy could be interpreted. At $80 \mathrm{kVp}$, the parts 6 through 9 of $\mathrm{Co}-\mathrm{Cr}$ alloy and parts 7 through

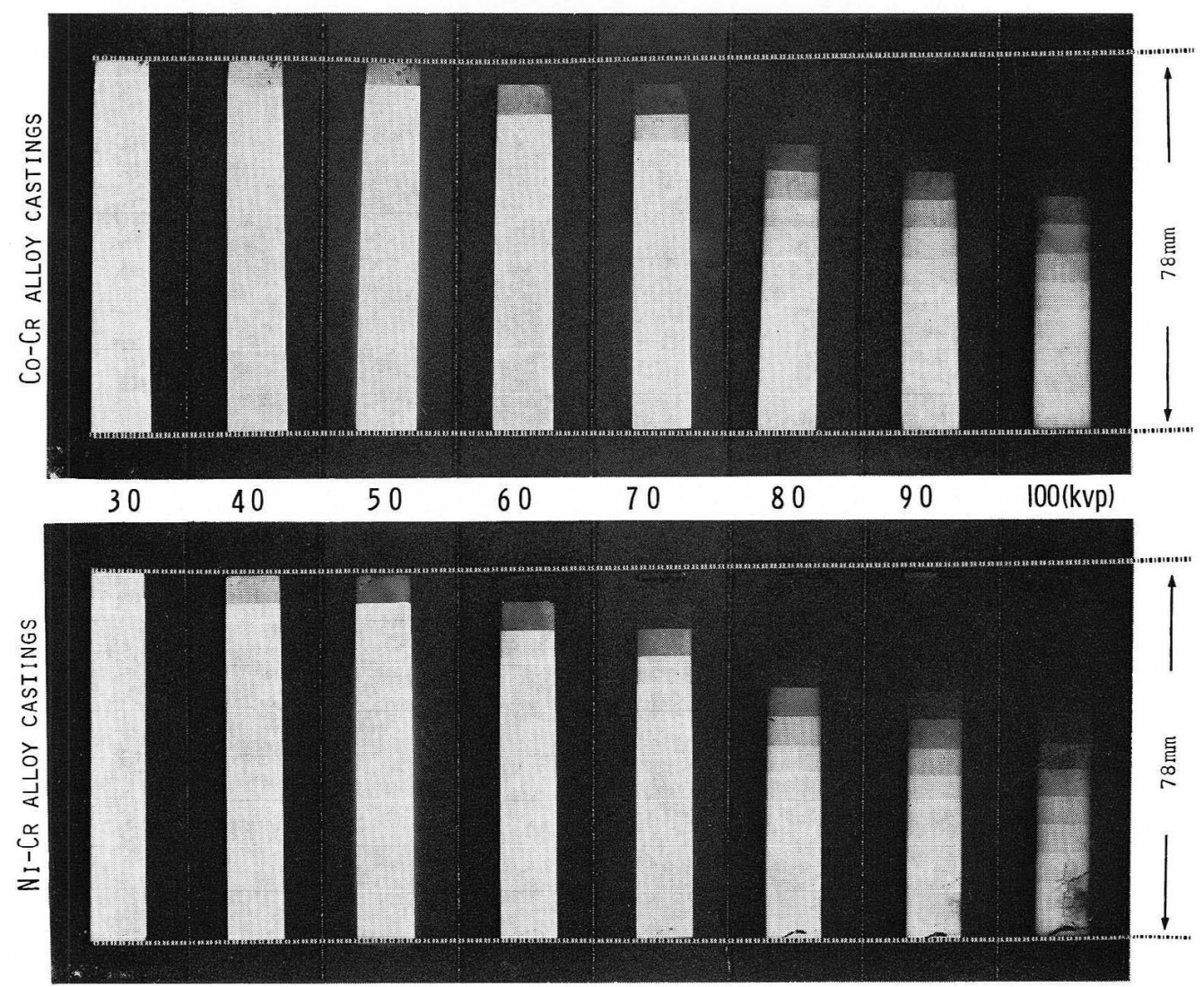

Figure 4 Radiographs of 120 seconds exposure with various tube voltages. 
10 of $\mathrm{Ni}-\mathrm{Cr}$ alloy could be interpreted. At $90 \mathrm{kVp}$, parts 8 through 13 of the both alloys, and at $100 \mathrm{kVp}$, parts 10 through 13 of both alloys could be interpreted (Figure 4).

90 seconds exposure: The result is shown in Figure 5. At $40 \mathrm{kVp}$, the interpretation on all parts of the test sample were impossible due to under-exposure. At $50 \mathrm{kVp}$, part 1 and at $60 \mathrm{kVp}$, part 2 of both alloys could be interpreted. At $70 \mathrm{kVp}$, parts 2 and 3 of $\mathrm{Co}-\mathrm{Cr}$ alloy and parts 3 and 4 of Ni-Cr alloy could be interpreted. At $80 \mathrm{kVp}$, parts 4 through 6 of $\mathrm{Co}-\mathrm{Cr}$ alloy and parts 5 through 7 of $\mathrm{Ni}-\mathrm{Cr}$ alloy could be interpreted. At $90 \mathrm{kVp}$, parts 5 through 10 of $\mathrm{Co}-\mathrm{Cr}$ alloy and 6 through 10 of $\mathrm{Ni}-\mathrm{Cr}$ alloy could be interpreted. However, the exposure density at parts 5 and 6 showed too high level of scale 7.5, which was the upper limit for densitometric interpretation. At $100 \mathrm{kVp}$, the both alloys could be interpreted in parts 8 through 13 . However, only part 13 showed low density of scale 4.0 which was the lower limit for the interpretation.

60 seconds exposure: The result is shown in Figure 6 . At $50 \mathrm{kVp}$, only part 1 of both alloys could be interpreted. At $60 \mathrm{kVp}$, only part 1 of $\mathrm{Co}-\mathrm{Cr}$ alloy could be interpreted, while only part 2 of $\mathrm{Ni}-\mathrm{Cr}$ alloy could be interpreted and part 1 showed over-exposure.
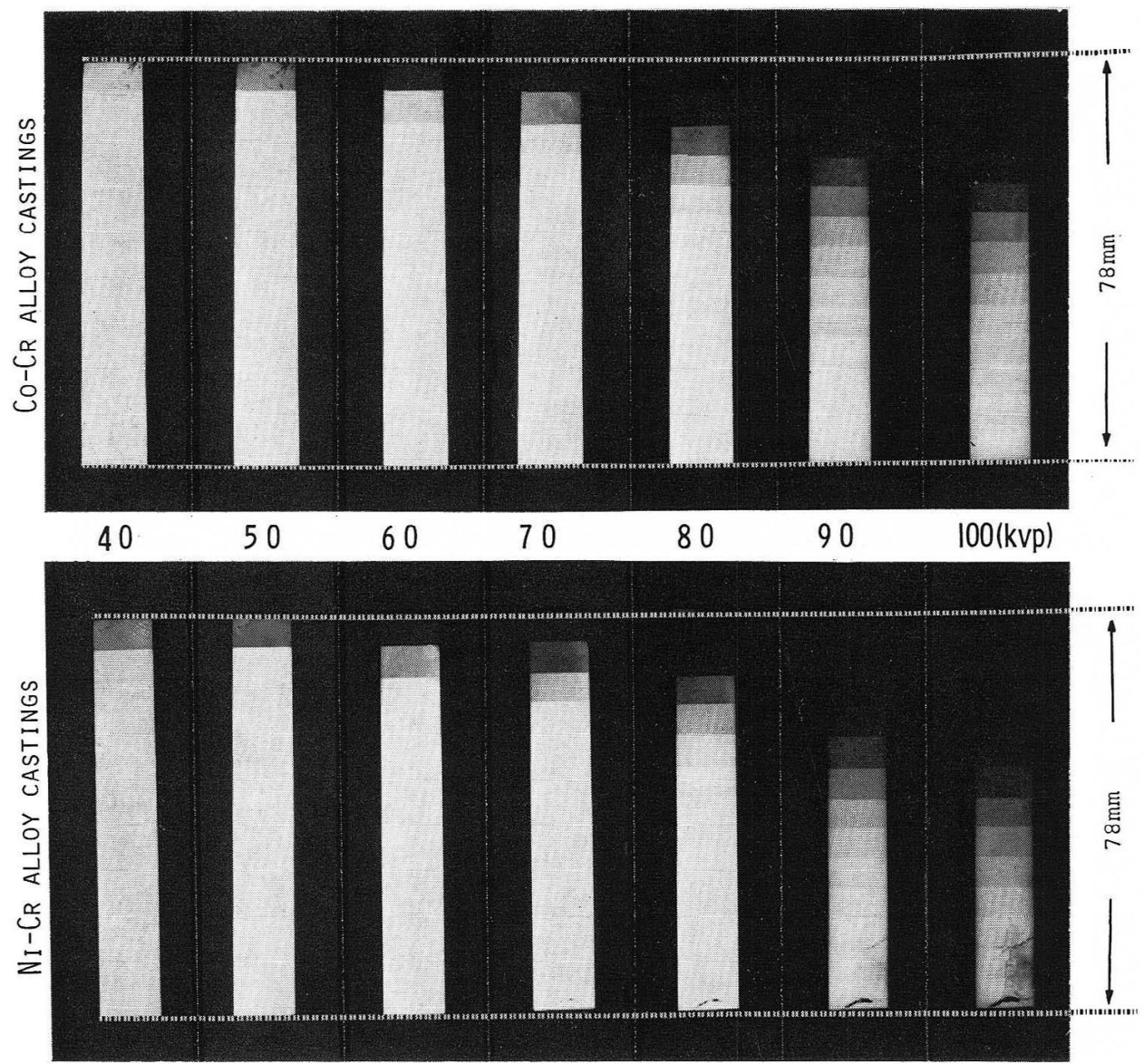

Figure 5 Radiographs of 90 seconds exposure with various tube voltages. 
At $70 \mathrm{kVp}$, part 2 of Co-Cr alloy and parts 2 and 3 of $\mathrm{Ni}-\mathrm{Cr}$ alloy could be inierpreted. At $80 \mathrm{kVp}$, parts 2 and 3 of $\mathrm{Co}-\mathrm{Cr}$ alloy and part 3 of $\mathrm{Ni}-\mathrm{Cr}$ alloy could be interpreted. At $90 \mathrm{kVp}$, parts 3 through 6 of both alloys could be interpreted. At $100 \mathrm{kVp}$, parts 6 through 13 of $\mathrm{Co}-\mathrm{Cr}$ alloy and parts 7 through 13 of $\mathrm{Ni}-\mathrm{Cr}$ alloy could be interpreted.

30 seconds exposure: The result is shown in Figure 7. At $60 \mathrm{kVp}$, only part 1 and at $70 \mathrm{kVp}$, parts 1 and 2 of both alloys could be interpreted, while at $80 \mathrm{kVp}$, parts 2 and 3 of both alloys and at $90 \mathrm{kVp}$, parts 2 through 4 of both alloys could be interpreted. At $100 \mathrm{kVp}$, the parts 3 through 6 of both alloys could be interpreted. However, part 6 was the upper limit. Under this exposure condition it seemed that more than $100 \mathrm{kVp}$ tubc voltage was necessary to interpret the part beyond part 7 .

These interpretation ability on the radiographs obtained with various exposure conditions of radiation was reconfirmed more clearly by utilizing densitometric measurement or each radiograph (Figures 8-10).

The results of clinical examination are shown in Figures 11-14, concerning previous exposure conditions. Small void and/or micro porosity were found clearly with wide spread within palatal region of cast frame at $60 \mathrm{kVp}, 90$ seconds exposure (Figure 11). Crack and gaps were found apparently within the joint region of between palatal strap and

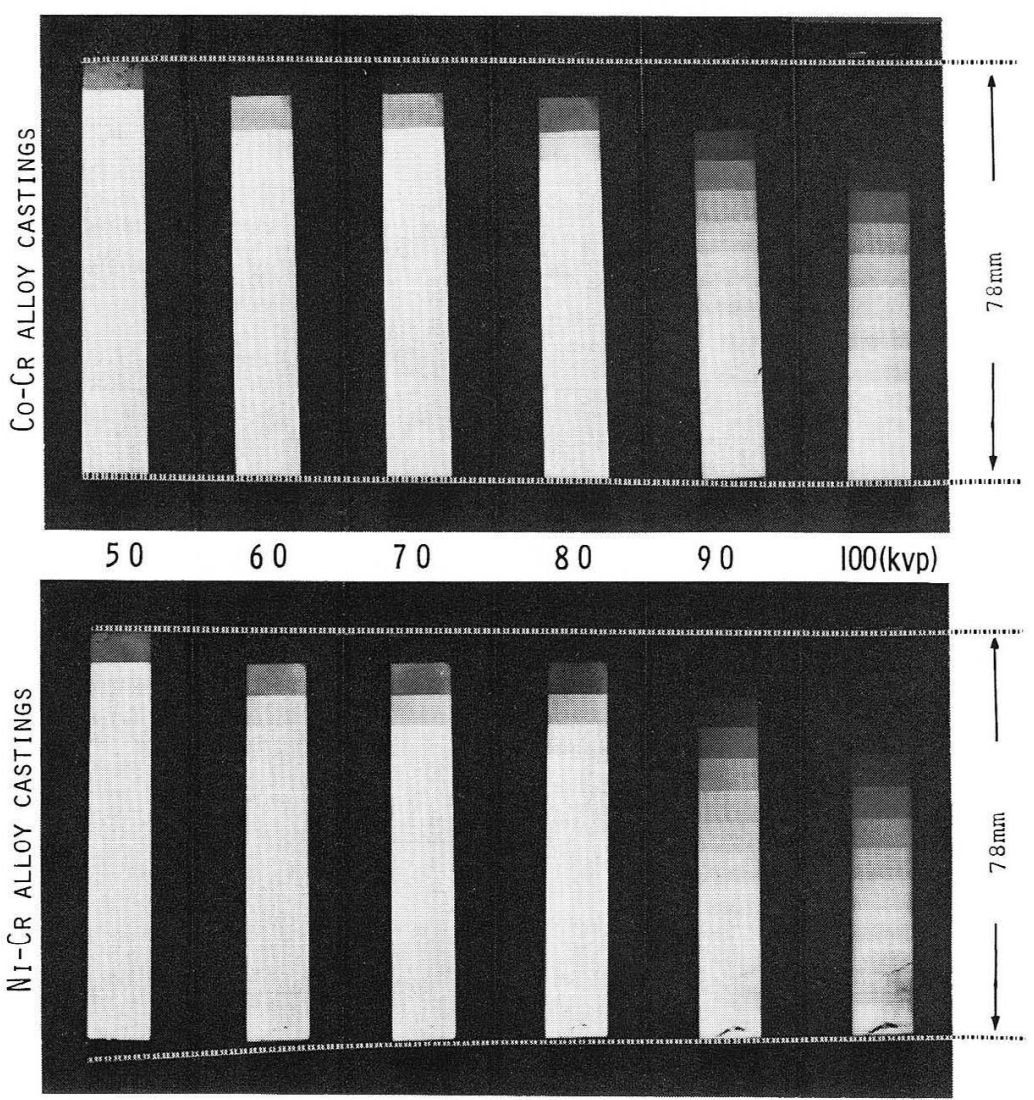

Figure 6 Radiographs of 60 seconds exposure with various tube voltages. 
retainer of partial denture frame at $70 \mathrm{kVp}, 90$ seconds exposure (Figure 12). Within the subperiosteal implants, many small gaps were found in the retention grid at $60 \mathrm{kVp}, 90$ seconds exposure (Figure 13). Within the crown shape castings, dendritic porosity and round shape porosity were clearly observed at $70 \mathrm{kVp}, 90$ seconds exposure (Figure 14).

\section{DISCUSSION}

Considering the significant influence of the casting porosities on mechanical strength of the casting, the experiments were carried out to examine the porosities by a non-destructive method with the Bio-X apparatus. Though there have been some reports on the observation of internal casting porosities by means of sectioning the castings, the few studies on the non-destructive radiographic observation have been reported ${ }^{9 \sim 11,13)}$. From the results of this experiment, it has become to be clear that Bio-X has suitable performance to evaluate the internal casting porosities. The difference between the both radiolucency of $\mathrm{Co}-\mathrm{Cr}$ alloy and $\mathrm{Ni}-\mathrm{Cr}$ alloy was noted, and $\mathrm{Ni}-\mathrm{Cr}$ alloy showed more radiolucency than $\mathrm{Co}-\mathrm{Cr}$ alloy. It is a well known fact that X-ray radiolucency is closely related to atomic weight and density of material. The specific gravities were 9.0 in $\mathrm{Co}-\mathrm{Cr}$ alloy of
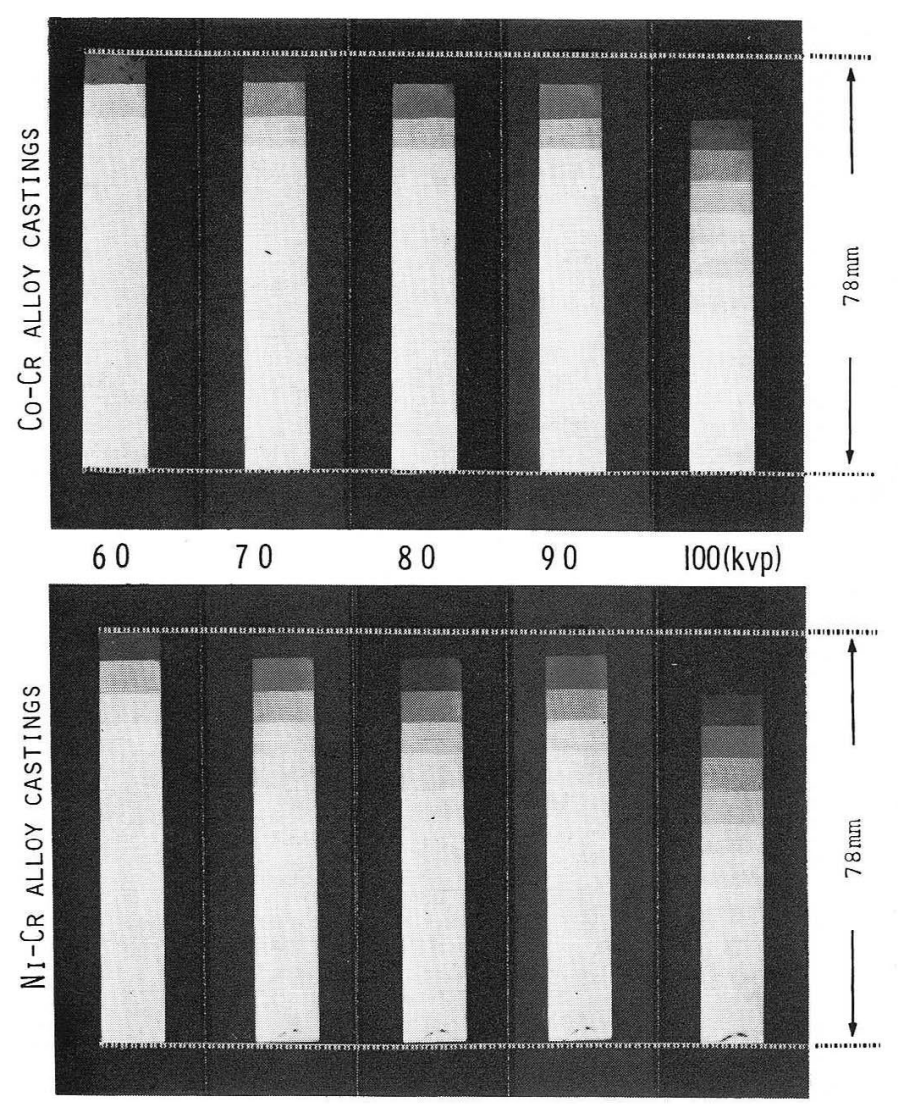

Figure 7 Radiographs of 30 seconds exposure with various tube voltages. 
Bionium and 8.0 in $\mathrm{Ni}-\mathrm{Cr}$ alloy of Wiron. It was assumed that the visual inspection on radiographs would not reveal difference between the two alloys. However, the densitometric method showed significant difference in radiolucency between the two alloys under all exposure conditions.

Though X-ray irradiation below $50 \mathrm{kVp}$ is used for wooden and plastic materials, it is not commonly used for metallic materials. However, since some dental csatings have such small thickness as about $0.35 \mathrm{~mm}$ or less, it is often necessary to use the low tube voltage for the metal plate of denture frame with particularly small thickness. With Bio$\mathrm{X}$ such low tube voltages as $20 \mathrm{kVp}$ and $30 \mathrm{kVp}$ were included for radiographical interpretation of the non-precious alloy castings with small thickness of $0.35 \mathrm{~mm}$ or less. Clear radiographs could not be obtained at $50 \mathrm{kVp}$ irrelevant to exposure time, when the thickness of the test sample under $0.7 \mathrm{~mm}$.

An dental castings have complicated shapes with various thickness depending on their clinical applications, it is extremely difficult to detect internal porosities in all part of dental casting with a single radiograph. In consideration of what is the most effective exposure for the all parts, the relation between $\mathrm{X}$-ray exposure time and $\mathrm{X}$-ray tube voltage were reviewed from the results of this experiments. As is shown in Figures 3 to 7 , it was at 90 seocnds exposure that clear radiographic views could be obtained throughout all ranges

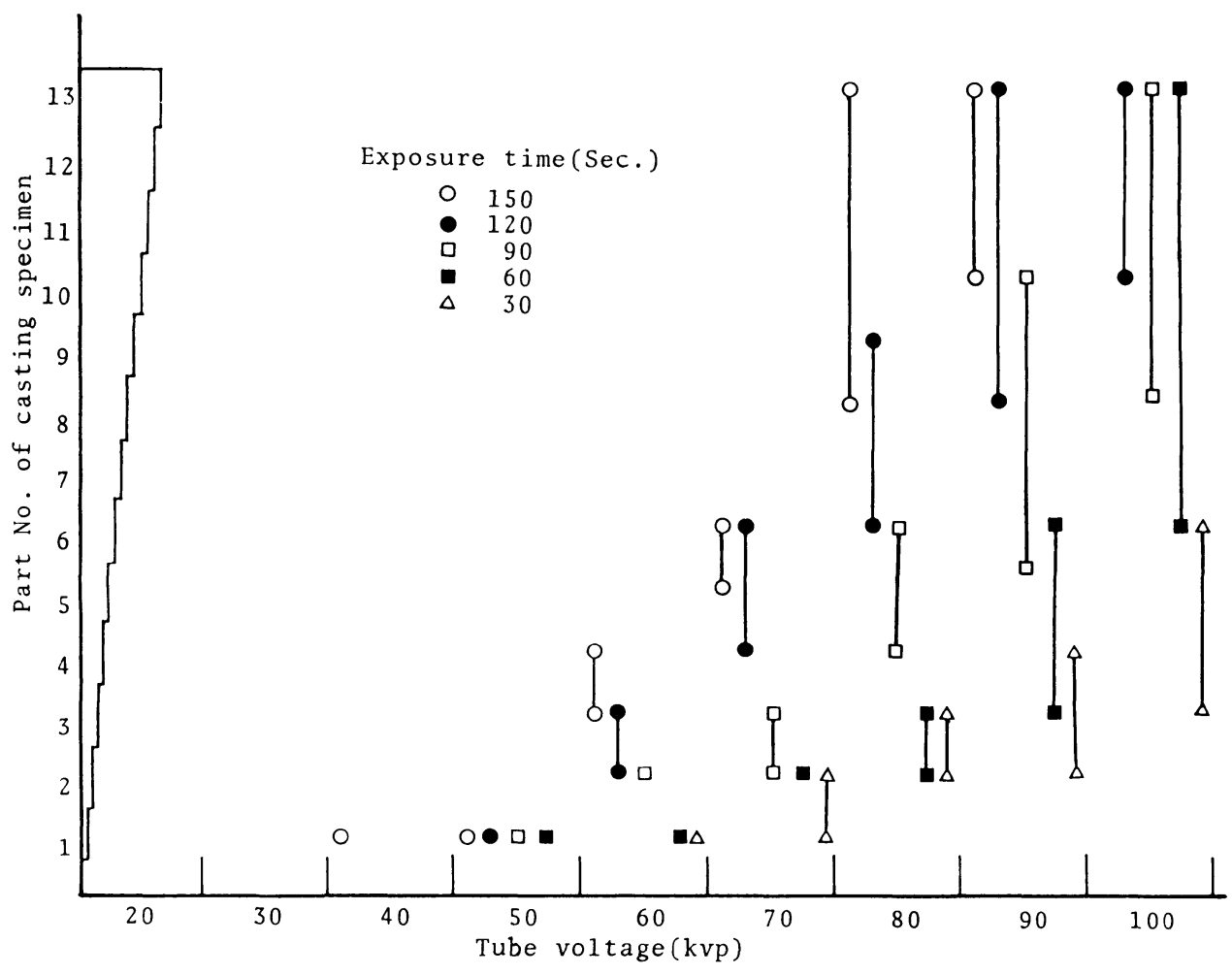

Figure 8 Suitable exposure range observed by densitometric measurement on cobalt-chromium test sample. 
of tube voltages with all parts being sufficiently observed with gradual overlapping. The radiographs obtained at the exposure for more than 120 seconds had the narrower range of allowance for interpretation at each tube voltage, and were undesirable to evaluate base alloy castings with uneven thickness. On the contrary the exposure for less than 60 seconds was effective only for the thinner parts of csatings, but it was almost impossible to interpret the thicker parts. It is revealed that 90 seconds exposure is the valid exposure condition for $\mathrm{Co}-\mathrm{Cr}$ and $\mathrm{Ni}-\mathrm{Cr}$ castings.

Radiolucency was related to the target size and the tube current density as well as the voltage. The target size of Bio-X is $1 \times 1 \mathrm{~mm}$, and the tube current is $5 \mathrm{~mA}$. If the target size and the tube current are increased, it will also increase the X-ray radiolucency. However, it must be done with caution, since clear radiographs may not be obtained easily due to difficulty of X-ray photography. As is known from the capacity of the apparatus, Bio$\mathrm{X}$ has the following properties in comparison with other $\mathrm{X}$-ray units; its target size is very small, and the tube current is low. These properties make it possible to obtain clearer and better radiographs with a simple technique and low cost than those obtained by other conventional units. This was also satisfactorily explained by the densitometric analysis. The wide range of suitable exposure was recognized by Bio-X, which produced useful radiograph to observe internal casting porosities of metallic dental restorations made of base

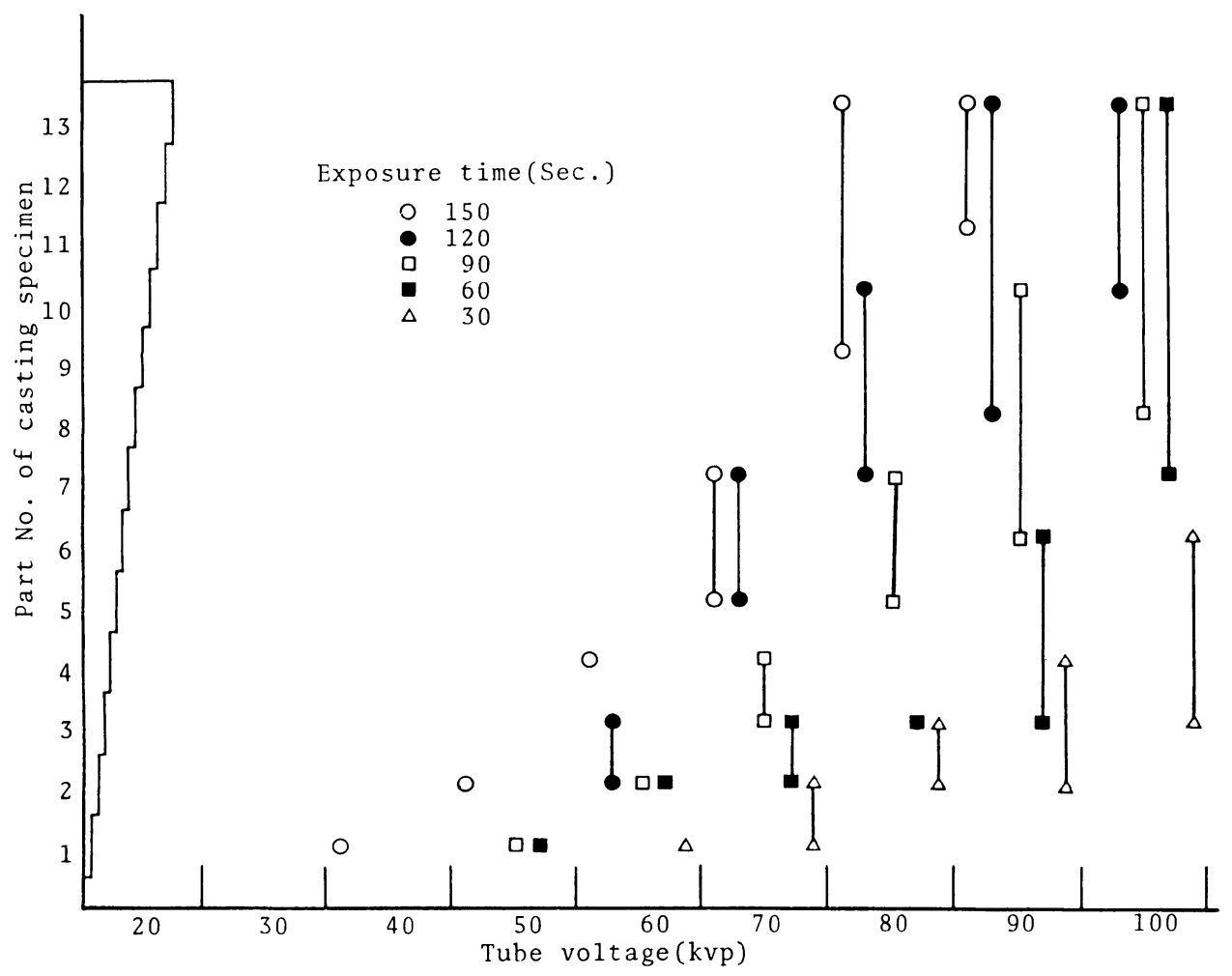

Figure 9 Suitable exposure range observed by densitometric measurement on nickel-chromium test sample. 
alloy. Microporosity or dendritic porosity as well as large porosity could be clearly interpreted with Bio-X and densitometer because micro difference of density of radiograph which was unidentified by the naked eye, can be well interpreted by the densitometric method.

The results interpreted by densitometric method (Figures 8 and 9) indicate clear cut difference of densities in a radiograph from scale 4.0 to 7.5 , which was represented more clearly in the recording chart (Figure 10). It is presumed that the combined use of the densitometer and non-destructive X-ray method realizes the very accurate observation for base alloy castings. Furthermore, it will be able to explain quantitatively the casting defects by automatic interpretation with photo-pattern analyser and computation.

\section{CONCLUSION}

An exlcusive X-ray unit was developed for the purpose of interpreting quantitatively internal porosities of base alloy castings.

It was found that the X-ray unit of Bio-X could provide clear radiographs. The results were as follows;

1) Microporosities of blow holes and dendritic defects were interpreted clearly by radiographical observation.
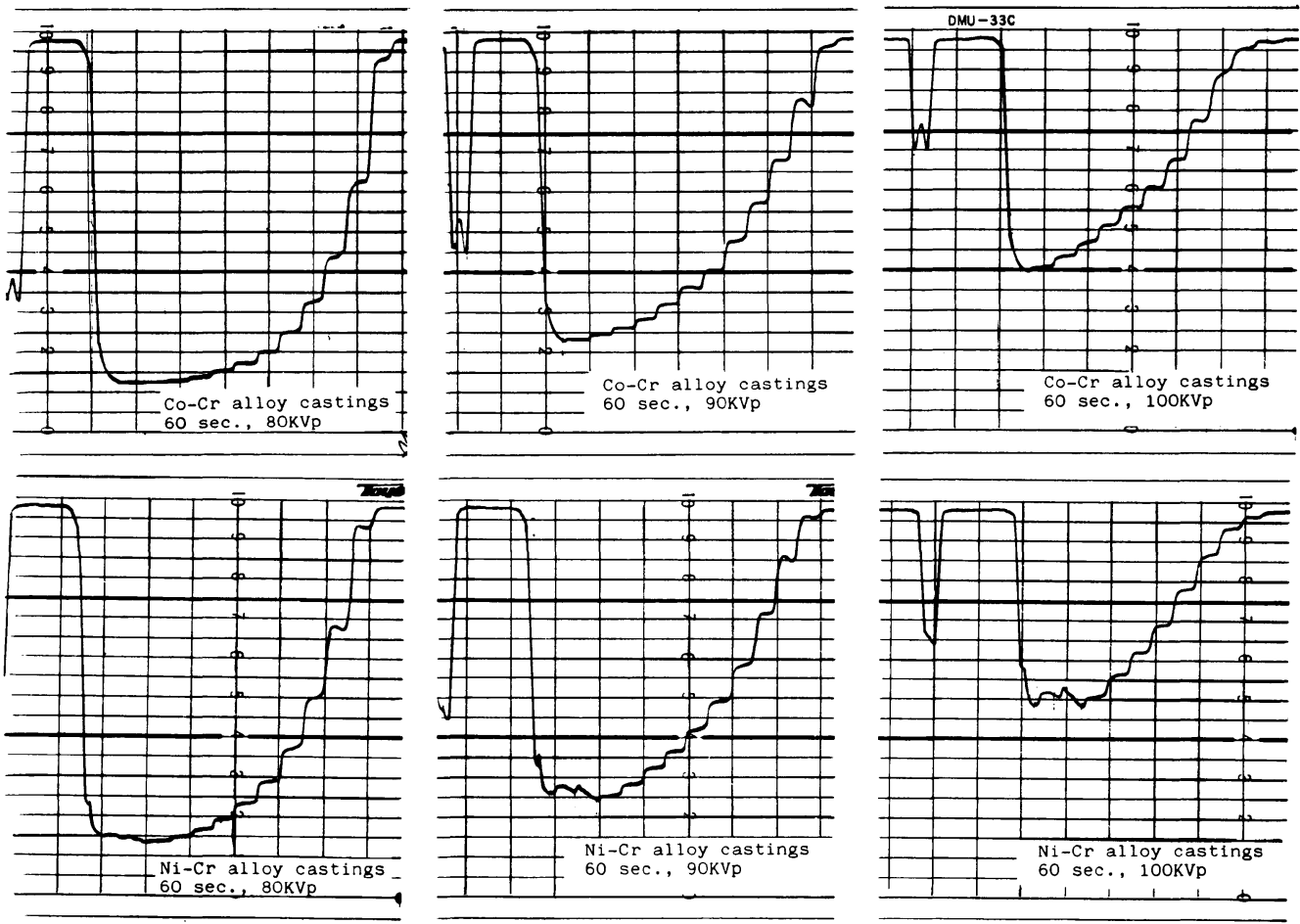

Figure 10 Densitometric levels upon the radiographs by using of densitometer (DMU-33C, Toyo). 


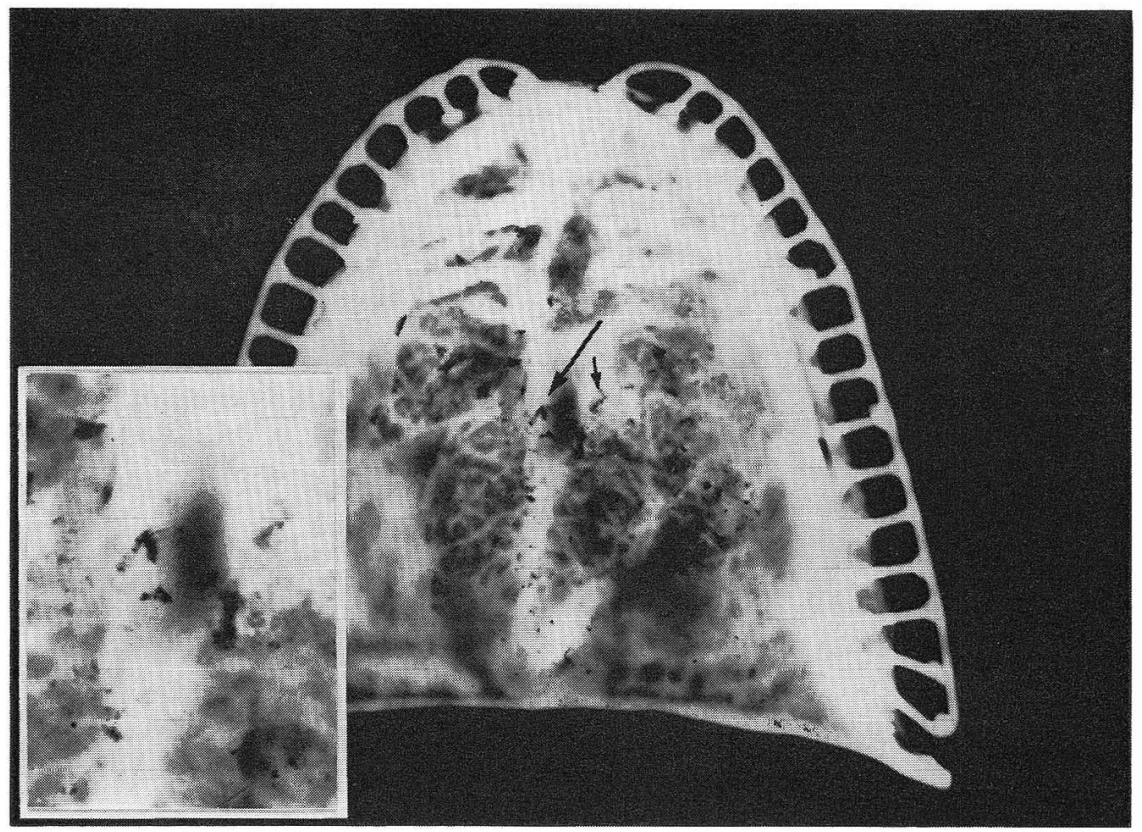

Figure 11 Widespread pin hole porosities in the palatal part of $\mathrm{Co}-\mathrm{Cr}$ cast denture frame.

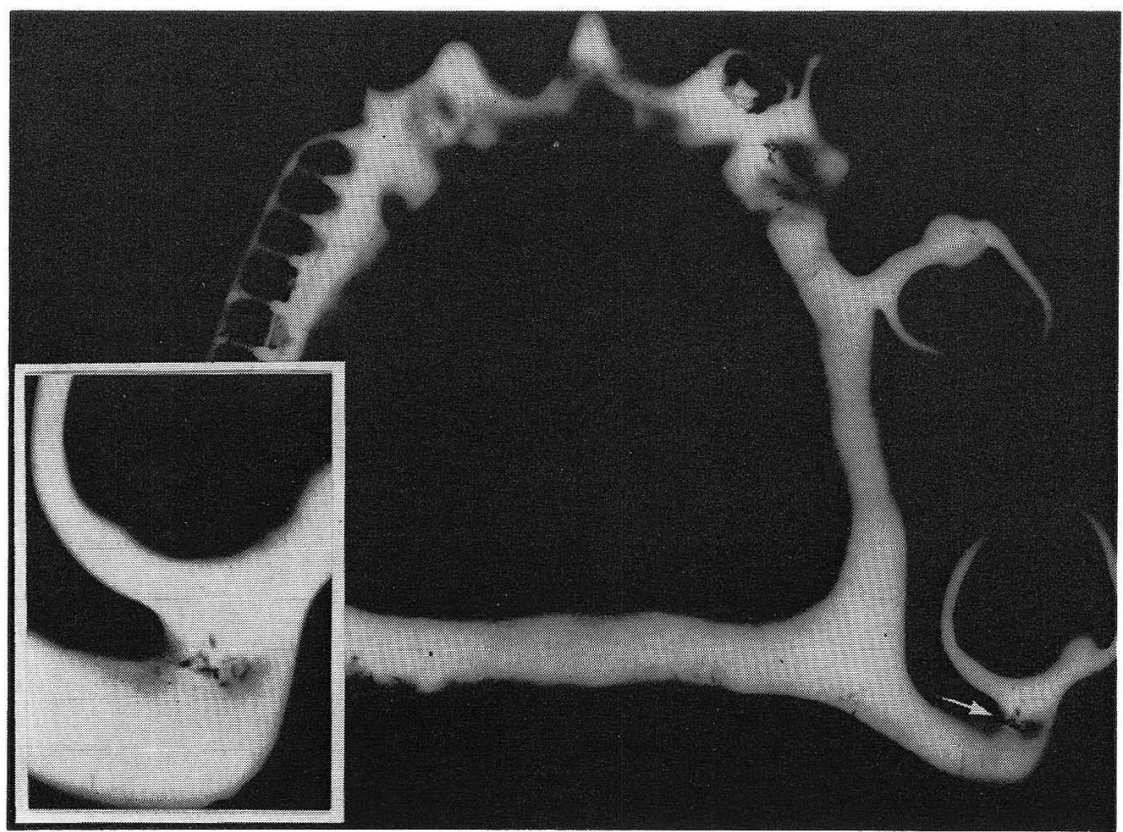

Figure 12 The bulkporosity in the clasp-palatal strap junction of $\mathrm{Co}-\mathrm{Cr}$ cast denture frame. 


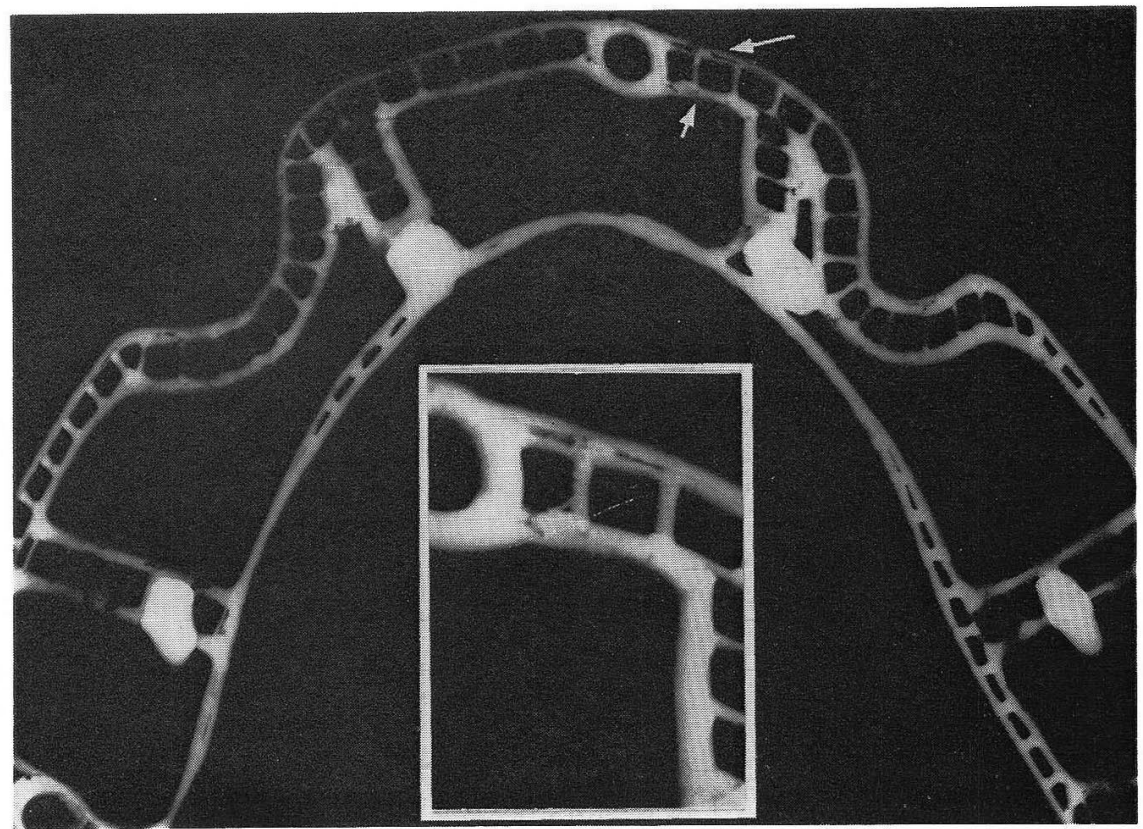

Figure 13 Small voides were contained in the retentive grid of subperiosteral implant.

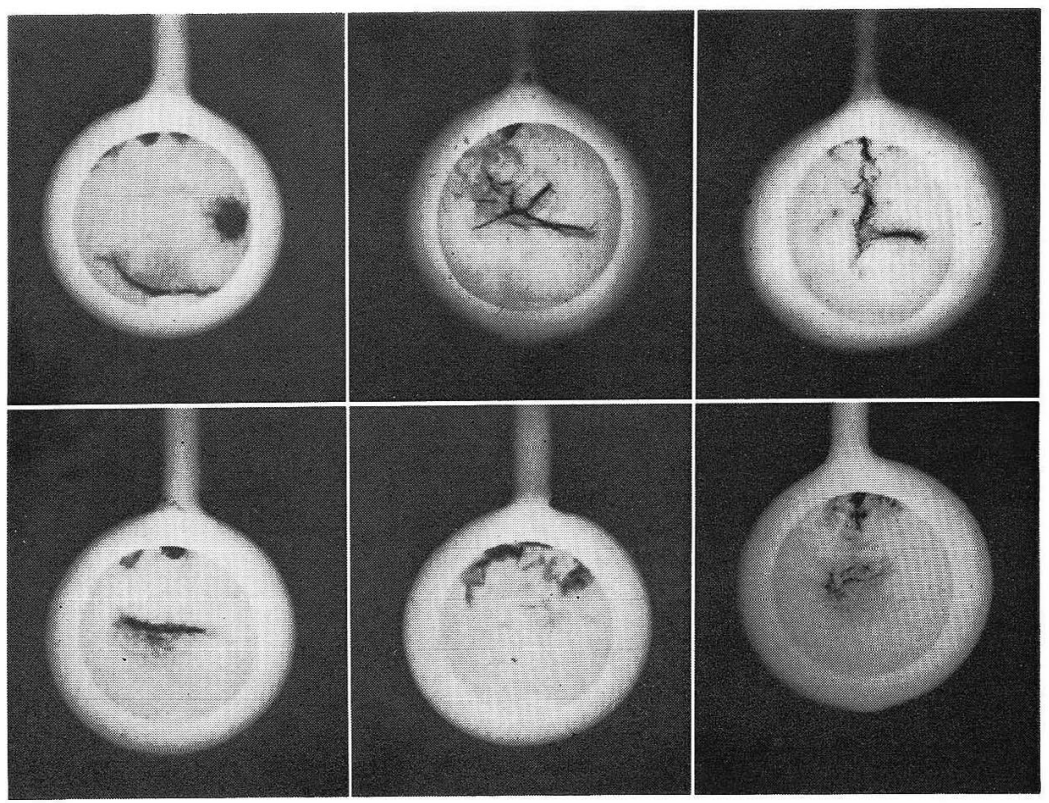

Figure 14 Various shape of internal defects were detected in oculusal region of base alloy crowns. 
2) It is easy to interpret the internal casting porosity of metal denture frame and crownbridge made of base alloy by setting the exposure time of 90 seconds and three tube voltages of 60,50 and $70 \mathrm{kVp}$ according to thickness of the castings.

3) It is desirable to provide three radiographs with three levels of under, medium and over exposute densities in order to interpret minutely the porosities in base alloy denture frame, crown-bridges and dental implants, which have complicated shapes and various thickness.

4) Under exposure is more effective to interpret micro porosities than at the over exposure.

\section{ACKNOWLEDGMENT}

The authors wish to thank Ass. Prof. T. Tamaki and Mr. M. Miyake for their collaboration and Ms. Y. Ohta for her assistances.

\section{REFERENCES}

1) Kawahara, H., Yamagami, A. and Nakamura, M.: Biological testing of dental materials by means of tissue culture, Inter. Dent. J., 18: 443-467, 1968.

2) Kawahara, H.: Biological problem of implant material, First Proceedings of JSID, 205-246, 1975.

3) Kawahara, H.: Biological evaluation of implant materials-Cell adhesion to material, Transaction of The 10th Annual Inter. Biomater. Symp., 2: 11-15, San Antonio, 1978.

4) Earnshaw, R.: Cobalt-chromium alloy in dentistry, Brit. Dent. J., 101: 67-75, 1956.

5) Asgaar, K. and Peyton, F.A.: Effect of microstructure on the physical properties of cobalt base alloys, J. Dent. Res $\times$. 40, 73-86, 1961.

6) Lewis, A.J.: Porosity in base metal partial denture casting alloys, related industrial alloys, and pure metals, Aust. Dent. J., 22: 208-211, 1977.

7) Lewis, A.J.: Radiographic evaluation of porosities in removable partial denture castings, J. Prosthet. Dent., 39: 278-281, 1978.

8) Scott, J. and Bates, J.F.: The effect of casting techniques on the mechanical properties of a dental cobalt-chromium alloy, J. Mater. Sci., 9: 464-458, 1974.

9) Kawahara, H., Ishizaki, N., Tani, S., Yokota, J., Koda, Y. and Kawamoto, T.: A study on the radiographic observation of high fusing dental alloy castings by Bio-X (MRO-10R), J. Jap. Soc. Dent. Apparat. Mater., 16: 234-248, 1975, (in Japanese).

10) Ishizaki, N., Kawahara, H., Kawamoto, T., Kataoka, K., Sogawa, K., Kobayashi, H., Kukizaki, H. and Miyake, M.: Efiect of spruing and air-vent upon casting defects in high fusible base alloy, J. Dent. Technics, 7: 457-467, 1979, (in Japanese).

11) Koda, Y.: Effect of spruing and air-vent upon casting defects within cobalt-chromium alloy castings, J. Osaka Odont. Soc., 43: 618-632, 1980, (in Japanese).

12) Tamaki, T., Kawahara, H. and Miyake, M.: Unilateral subperiosteal implant-Bionium casting system-, First Proceedings of JSID, 261-278, 1975.

13) Tani, S.: Origination of casting porosities of high fused dental alloy by used of Bio-X X-ray unit (MRO-10R), J. Jap. Soc. Dent. Apparat. Mater., 18: 193-208, 1977, (in Japanese). 


\section{クロルヘキンジン塩酸塩を配合した 抗菌性根管充填用ンーラーに関する研究}

第 1 報 ベースとなるシーラーの組成の影響について

南部敏之

京都大学医用高分子研究センター歯科材料応用研究部門

酸化亜鉛ユージノール系のシーラーについて, 酸化亜 鉛の熱処理やロジンの配合量の違いが，硬化時間と封鎖 性に与える影響を検討した。酸化亚鉛とチョウジ油の練

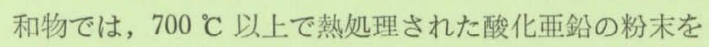
用いた場合, 急激に硬化時間が延長した。また処理温度 700 ○ の粉末を用いた場合に封鎖性は最あ良くなった。 この練和物へのロジン配合率について，5１5\%の場合 硬化時間は延長したが, 配合率が増加するにつれ短 縮
し，30\%で最小值となった。この傾向は硬化機序におけ るロジンの影響が大きいととを示唆している。封鎖性は 配合率の増加につれ良くなったが, 臨床におりる操作性 の点で, 過大な粘着性をむつ配合率40\%以上のものは実 用的ではない。これらより抗菌性を持つシーラーのベー スとしての酸化車鉛ユージノール系シーラーは, 700 ㅇ で熱処理した酸化业鉛を含み，ロジンが30\%配合されて いるものが適しているといえる。

\section{X線による高溶卑金属合金鋳造体の非破壊検査}

川原春幸, 石崎順啓, 前田孝俊, 栄 弘毅

\section{大阪歯科大学歯科理工学教室}

コバルト・クロム系扰よびニッケル・クロム系合金は 耐食性にすぐれ機械的強度も大きく軽量で, しかす生体 組織へのなじみあ良好である。さらに精密鋳造成形法に ついてあほぼ確立され, 比較的精度の良い鋳造体が得ら れるようになってきた。最近では鋳造床のみならずクラ ウンーブリッジ，メタルボンドポーセレンさらにインプ ラント用として広く活用されようとしている。しかしこ の種の合金には鋳造欠宿が多発するという大きな難点が ある。とくに内部鋳造欠宿の発生は鋳造成形物の機械的 性質や耐食性を著しく低下させ生物学的にも種々の問題 を包含している。そてで鋳造体内部の欠陷の発生機構を 解析し, 欠陥防止法を究明するために菌科鋳造体専用の X線装置を開発し，その性能を調べるととあにいくつか の実験を行ってみた。すなわち,コバルト・クロム合金 (Bionium) およびニッケル・クロム合金 (Wiron) で鋳 造成形された階段状の test piece を使用した。 test pie- ce の厚径は $0.35 \mathrm{~mm}$ から $4.55 \mathrm{~mm}$ までを $0.35 \mathrm{~mm}$ ご とに13段階にしたものである。なお，臨床実験例として コバルト・クロム合金による鋳造床とクラウン，骨膜下 インプラントの下部構造体などの内部欠陥を観察した。

その結果, 歯科鋳造体専用 X線装置 $(\mathrm{Bio}-\mathrm{X})$ を用い ることによってきわめて鮮明なX線像が得られるととが 分かった。本法によればブローホールや樹枝状鋳巣のよ うな微細な欠陷まで観察が可能で，とくに管電圧 50,60 および $70 \mathrm{KVp}$ で90秒間の嚗写条件でコバルト・クロム 系およびニッケル・クロム系合金鋳造体内部のほとんど の欠陥が観察された。

以上のととから，X線による金属鋳造体の非破壊検査 は臨床上非常に有用なあのであるととが理解できた。と くに鋳造性能のよくない高溶龵金属金鋳造体については 臨床応用以前における必須の検查法として採用すべきで あろう。

DSC 等温法飞よるジメタクリレートモノマーの重合発熱の研究

伴 清治, 長谷川二郎

愛知学院大学歯学部歯科理工学教室 